\title{
DINO COMPAGNI'S \\ CHRONICLE OF FLORENCE
}


The Middle Ages

a series edited by

EDWARD PETERS 


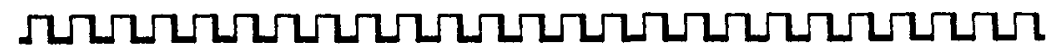

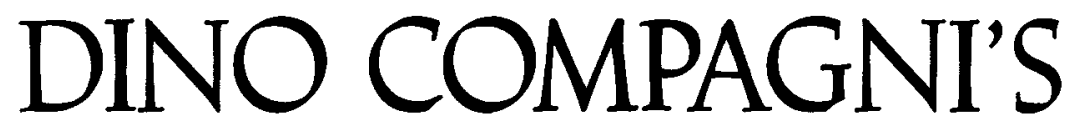

CHRONICLE OF FLORENCE

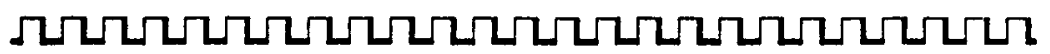

TRANSLATED, WITH AN INTRODUCTION AND NOTES, BY DANIEL E. BORNSTEIN

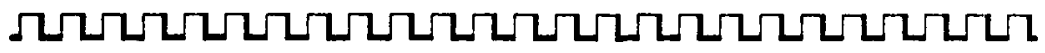

Uh University of Pennsylvania Press · Philadelphia · 1986 
Copyright (C) 1986 by the University of Pennsylvania Press All rights reserved

Designed by Adrianne Onderdonk Dudden

Printed in the United States of America

Library of Congress Cataloging-in-Publication Data

Compagni, Dino, 1260 (ca.) -1324.

Dino Compagni's Chronicle of Florence.

(The Middle Ages)

Translation of: Cronica delle cose occorrenti ne' tempi suoi.

Includes index.

1. Florence (Italy)-History-To 1421. I. Title.

II. Title: Chronicle of Florence. III. Series.

DG737.2.C73213 $1986 \quad 945^{\prime} .51$

85-29517

ISBN 0-8122-8012-1 (alk. paper)

ISBN 0-8122-1221-5 (pbk.: alk. paper) 


\author{
For Eric Cochrane \\ dedicated historian \\ and \\ buon cittadino popolano
}


This page intentionally left blank 